\title{
Diabetes care in the early primary school setting: narratives of Australian mothers
}

\section{AUTHORS}

ANNE L MARKS ${ }^{1}$

NATHAN J WILSON ${ }^{1}$

STACY BLYTHE ${ }^{1}$

CHRISTINE JOHNSTON ${ }^{2}$

\section{CORRESPONDING AUTHOR}

ANNE L MARKS School of Nursing and Midwifery, Western Sydney University, Locked Bag 1797, Penrith, NSW 2751, Australia. Phone: +61 24570 1599. Email: anne.marks@westernsydney.edu.au
1 School of Nursing and Midwifery, Western Sydney University, Penrith, NSW Australia.

2 School of Education, Western Sydney University, Penrith, NSW, Australia.

\section{ABSTRACT}

Objective: To explore the experiences of Australian parents caring for a child using intensive insulin therapy in the early primary school setting to identify facilitators of this therapy and implications for parents.

Background: Young children with type 1 diabetes require adult support when administering insulin in the early primary school setting, yet availability of school support, such as from nurses, is inconsistent across Australia. This increases the burden on parents and in some circumstances, insulin is avoided at school.

Study design and methods: This study was a qualitative research design using narrative inquiry. Mothers ( $n=14$ ) from six Australian states/territories with children attending Government, Catholic and Independent schools participated in semi-structured telephone interviews between December 2014 and September 2016. Narrative analysis was used to interpret the interview data.

Results: Nine narrative threads told the collective story of mothers' experiences supporting their child with intensive insulin therapy at school. Facilitators of intensive insulin therapy were collaborative partnerships between parents and school staff, diabetes education for school staff, reasonable adjustments for integrated care and the use of continuous glucose monitoring systems. Implications for mothers were the stigma of advocating, being worried about their child's safety in other people's care, restricted employment, wanting their child to be like everyone else, and providing 24/7 care behind the scenes. Despite these challenges, all children received intensive insulin therapy at school.

Discussion and conclusion: The findings of this study indicate that the Australian education system lacks appropriate health support structures required for children with type 1 diabetes. In order to facilitate diabetes care at school non-nursing staff are trained to administer or supervise insulin and the overall responsibility is transferred onto parents.

Implications for policy and nursing practice: Nurses working as diabetes educators need to be aware of the burden on parents and advocate for more supportive practices to facilitative intensive insulin therapy in the early primary school setting. Parents, in collaboration with health and education departments, should demand the allocation of appropriately qualified school nurses to legally provide high quality diabetes care that children are entitled to. If current practices, dictated by insufficient resources continue, the Australian Government will make the assumption that existing systems are adequately meeting the needs of students with type 1 diabetes. 
What is already known about the topic?

- Children with chronic health conditions have a high risk of poor educational outcomes.

- Most Australian schools do not employ nurses. Teaching and administration staff are frequently used for healthcare support including the management of diabetes.

What this paper adds:

- This study is the first to provide qualitative insight into the experience of Australian mothers supporting their child with type 1 diabetes using intensive insulin therapy in the early primary school setting.
- The findings highlight the significant physical, emotional and financial impact on mothers who support intensive insulin therapy.

- This paper provides an awareness of the disconnect between mandatory school attendance, accessing education on the same basis as others according to the Disability Standards for Education, and the availability of school nurses to legally administer insulin.

Keywords: Chronic illness; diabetes; nursing; nurse; primary school; parenting

\section{BACKGROUND}

Type 1 diabetes mellitus (T1DM) is a metabolic disorder characterised by a deficiency in insulin secretion leading to hyperglycaemia. ${ }^{1}$ Approximately 96,000 children aged less than 15 years develop T1DM worldwide each year and around 500,00o children are currently living with T1DM. ${ }^{1}$ The mean annual incidence for Australian children aged o-4 years is 15.1 per 100,000 and 26.4 per 100,000 for children aged 5-9 years. ${ }^{2}$ In 2019, approximately 7,00o Australian children aged o-14 years were living with T1DM. ${ }^{3}$

Like other childhood chronic conditions T1DM affects quality of life including physical, social and emotional development and increases a child's vulnerability when entering and progressing through the school system. ${ }^{45}$ Children with chronic health conditions have a high risk of poor educational outcomes related to disrupted class attendance and the possible cognitive impacts of their underlying condition. ${ }^{6}$

The recommended treatment for T1DM is intensive insulin therapy (multiple daily injections or an insulin pump) supported by carbohydrate counting and regular blood glucose level testing.7. ${ }^{7}$ This reduces the risk of microvascular and macrovascular disease and should be initiated at diagnosis. ${ }^{8-11}$ Despite the obvious benefits, intensive insulin therapy (IIT) creates challenges for early primary school children (the first three years of compulsory school), due to the complexity of insulin treatment and their young developmental stage, necessitating the reliance on adult support for diabetes care during the school day.

School attendance is compulsory in Australia and most Western countries. ${ }^{12,13} \mathrm{~T} 1 \mathrm{DM}$ is recognised as a disability in The Australian Disability Standards for Education based on the Disability Discrimination Act 1992. 14,15 According to these standards schools have legal obligations to make reasonable adjustments for students with T1DM to enable participation in the curriculum on the same basis as their peers. This is consistent with the law in a number of other countries. ${ }^{16-19}$
However, reasonable adjustments for early primary school (EPS) students with T1DM can be complex due to the need for insulin administration, a prescription only medication with limited legal rights for possession (medical practitioners and endorsed nurses). ${ }^{20-23} \mathrm{~A}$ parent or "Agent" of the parent, for example non-nursing school staff, may also be legally authorised when nurses are not available. ${ }^{24-27}$ Parents can grant Agency (after informed consent) to a school staff member who has; (a) freely volunteered, (b) completed appropriate training and (c) been deemed competent by the parent. This applies to both supervision and administration of insulin therapy. The limited availability of school nurses in Australia and therefore the need for an "Agent" creates problems, as non-nursing school staff must freely volunteer. The reluctance of school staff to provide support is often due to the invasive nature of IIT and fear of liability, as health procedures are outside the scope of practice of non-nursing staff. ${ }^{28}$ In most countries, there is no legal duty for nonmedical personnel to administer or supervise medication. ${ }^{29,30}$

When support for diabetes care is not provided by school staff, often parents or the student administer insulin. ${ }^{6}$ Ongoing provision of care has significant impacts on parental employment, socioeconomic status, $, 31,34,35$ and emotional wellbeing. 13,31-33 If support from school staff or parents is unavailable, and the student is unable to selfcare, insulin is avoided for some children and has potential negative consequences for immediate and long-term health and wellbeing. ${ }^{6,31}$

Although there are a number of studies about parental concerns around the care of T1DM at school, 13,31,32, 34-38 qualitative research focusing specifically on EPS and IIT in the Australian context is limited. This paper explores the experiences of Australian parents caring for a child using IIT in the EPS setting to identify facilitators of this therapy and implications for parents. It is part of a larger body of research and published work encompassing the experiences of diabetes educators ${ }^{39}$ and primary school teachers. $4^{\circ}$ 
It is important for nurses to understand the facilitators and implications of IIT support from the parents' perspective. Parents as advocates and legal guardians of their child are the end users of the health system. They provide a significant amount of diabetes care for children in the EPS age group and are central to their overall wellbeing. Findings from this study have the potential to benefit nurses from various settings including diabetes education services, hospital paediatric wards, child and family health services and schools. In particular, parental perspectives from this study are important for speciality nurses employed as Credentialled Diabetes Educators ${ }^{41}$ working closely with children, families and significant others such as school staff. Understanding the narratives of other stakeholders involved in facilitating IIT in the EPS setting enhances family centred care, partnership and collaboration.

Findings from this study will inform both the education and health sectors to guide resource allocation to improve both diabetes care for EPS children and parental health and wellbeing.

\section{METHOD}

\section{METHODOLOGY}

Narrative inquiry methodology was used in this study. Explanatory stories collected from interview data, provide knowledge of particular situations in an attempt to understand individual personal experiences. ${ }^{42}$ Examining how and why a particular outcome occurred by collecting descriptions of past events and actions, enables planning for future action and informs practice. ${ }^{43}$ Unlike quantitative data, qualitative interview data provide rich descriptions of personal experiences. Narrative inquiry methodology has been widely used in both health and educational research. ${ }^{44-48}$

\section{PARTICIPANTS}

Participants were purposively recruited between December 2014 and September 2016. The inclusion criteria were parents caring for a child with T1DM who was:

- attending an Australian primary school in Kindergarten, Year 1 or 2

- using IIT (insulin pump or multiple daily injections)

- receiving an insulin bolus or injection at school

Participants were also required to speak English. Parents were recruited via posts on ten Facebook diabetes support groups. Twenty one mothers responded to the Facebook posts and fourteen participated in the study. There was no response to this recruitment method from fathers.
Ethical approval for this study was gained from the Western Sydney University Human Research Ethics Committee (Approval number H10811). A research information sheet was emailed to interested participants and discussed prior to the interview. Written consent for the study was documented by a signed consent form.

\section{PROCEDURE}

The geographical distribution of participants precluded face-to-face interviews. Therefore, telephone interviews were conducted by the first author, a nurse practitioner, Credentialled Diabetes Educator and skilled interviewer. Open-ended questions and a semi-structured interview guide were used to stimulate discussion about participants' experiences of supporting IIT in the EPS setting. The interview guide was developed after review of the literature and consisted of six broad questions to address the study aims (Table 1 ). ${ }^{28}$ Additional questions and probes from the interviewer were based on individual participant responses.

\section{TABLE 1. INTERVIEW GUIDE}

1. What happened when your child returned to/started school after being diagnosed with diabetes?

2. Who was involved with the transition to school?

3. How did you feel about the process?

4. Can you tell me about your experience of using insulin injections or insulin pump therapy for your child at school?

5. What are the challenges of using this therapy at school, if any?

6. How does this therapy impact on you as a parent?

\section{DATA ANALYSIS}

Narrative analysis, as informed by narrative cognition, involves noting difference and diversity within interactional and temporal contexts to provide an understanding of human action. ${ }^{44,49}$ This method was used to interpret the interview data to produce explanatory stories from descriptions of events and actions (narrative elements). ${ }^{44}$ Narrative cognition results in 'good stories' that are detailed, sequential and oriented towards action; they deal with the particulars of experience in time and place. ${ }^{49}$ The data analysis process and trustworthiness are summarised in Tables 2 and 3 . 


\section{TABLE 2. DATA ANALYSIS PROCESS}

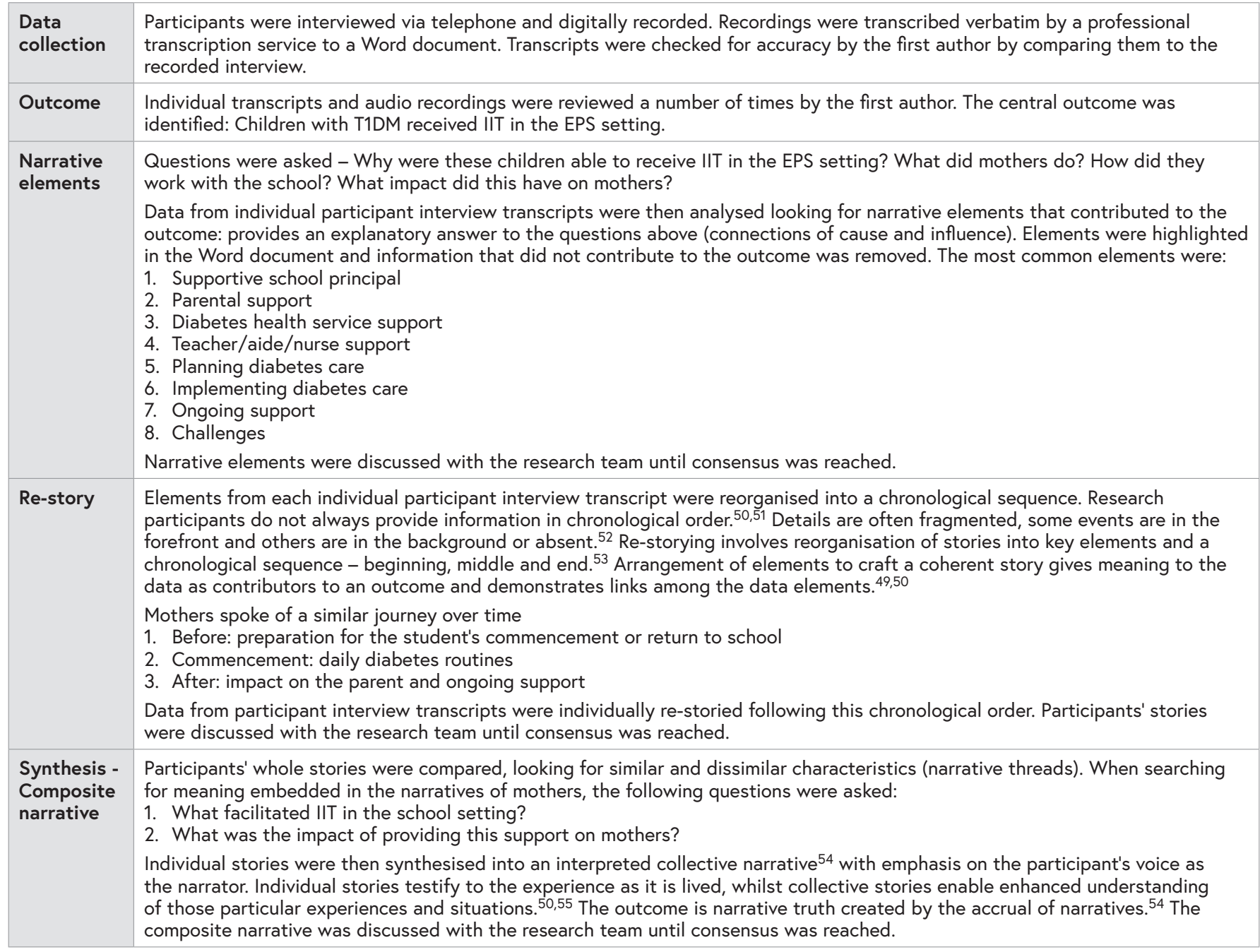

\section{TABLE 3. DATA TRUSTWORTHINESS}

\begin{tabular}{|l|l|}
\hline Credibility & $\begin{array}{l}\text { The first author reflected on potential bias due } \\
\text { to personal experience as a Diabetes Educator } \\
\text { throughout the research process. To minimise bias, } \\
\text { regular review and discussion with members of } \\
\text { the research team was conducted (two registered } \\
\text { nurses - who were not Diabetes Educators and } \\
\text { one teacher educator). }\end{array}$ \\
\hline Dependability & $\begin{array}{l}\text { The research design, data collection and analysis } \\
\text { are clearly stated, demonstrating transparency in } \\
\text { the decision making process. }\end{array}$ \\
\hline Confirmability & $\begin{array}{l}\text { Raw interview data were frequently reviewed } \\
\text { during analysis. An audit trail of the decision } \\
\text { making process is provided in the methods } \\
\text { section. Findings and conclusions reflect the study } \\
\text { aim and have clear connections to the interview } \\
\text { data. }\end{array}$ \\
\hline Transferability & $\begin{array}{l}\text { Recruitment procedures and participants are } \\
\text { described and the sample is from six out of eight } \\
\text { Australian states/territories. Rich participant } \\
\text { narratives have been included and findings are } \\
\text { comparable to other research literature and } \\
\text { settings. }\end{array}$ \\
\hline
\end{tabular}

\section{FINDINGS}

\section{CHARACTERISTICS OF PARTICIPANTS}

Study participants were female (mothers $n=14$ ) with children in either the first year of school, Grade 1 or Grade 2, from five Australian States and the Australian Capital Territory, and included various school types and geographical locations (Table 4). Nil participants withdrew from the study, there were no adverse events to report, and pseudonyms for both mothers and children have been used in this paper to maintain anonymity.

Nine narrative threads were evident during the synthesis process (Table 5). The findings are presented as a composite (collective) narrative with emphasis on the participants' voice (in italics) as the narrator, rather than the researcher. This approach allows the 'telling of the story' in the mothers' own words and aims to give the reader a deeper, more personal understanding of their experiences. 
TABLE 4. PARTICIPANT DEMOGRAPHIC DATA: MOTHERS ( $\mathrm{N}=14$ )

\begin{tabular}{|c|c|c|c|c|c|c|c|c|}
\hline & Mother & $\begin{array}{l}\text { State/ } \\
\text { Territory }\end{array}$ & $\begin{array}{l}\text { Geographic } \\
\text { Location }\end{array}$ & School type & $\begin{array}{l}\text { School } \\
\text { grade }\end{array}$ & $\begin{array}{l}\text { Insulin } \\
\text { delivery } \\
\text { device }\end{array}$ & Insulin administration & $\begin{array}{l}\text { Student } \\
\text { gender }\end{array}$ \\
\hline 1. & Susan & NSW & RA2 inner regional & Government & 2 & Injections & $\begin{array}{l}\text { Mother/student in school } \\
\text { office }\end{array}$ & Female \\
\hline 2. & Rhonda & NSW & RA1 major city & Independent & 1 & Injections & $\begin{array}{l}\text { School nurse in the } \\
\text { classroom }\end{array}$ & Female \\
\hline 4. & Amy & NSW & RA1 major city & Government & 1 & Pump & $\begin{array}{l}\text { Student with class teacher } \\
\text { supervision in the classroom }\end{array}$ & Female \\
\hline 5. & Jaylene & QLD & RA1 major city & Catholic & 2 & Pump & $\begin{array}{l}\text { Student with class teacher/ } \\
\text { aide supervision in the } \\
\text { classroom }\end{array}$ & Female \\
\hline 6. & Sharon & QLD & RA1 major city & Government & 2 & Pump & $\begin{array}{l}\text { Student with class teacher } \\
\text { supervision in the classroom }\end{array}$ & Male \\
\hline 7. & Maria & VIC & RA1 major city & Catholic & 1 & Pump & $\begin{array}{l}\text { Student with class teacher/ } \\
\text { aide supervision in the } \\
\text { classroom }\end{array}$ & Male \\
\hline 8. & Louise & QLD & RA2 inner regional & Government & 1 & Pump & $\begin{array}{l}\text { Student with teacher aide } \\
\text { supervision in the classroom }\end{array}$ & Male \\
\hline 9. & Elizabeth & QLD & RA2 inner regional & Government & 2 & Injections & Teacher's aide in classroom & Male \\
\hline 10. & Rachel & VIC & RA1 major city & Government & Preparatory* & Pump & $\begin{array}{l}\text { Registered Nurse in the } \\
\text { classroom }\end{array}$ & Male \\
\hline 11. & Melissa & WA & RA3 outer regional & Catholic & 1 & Pump & $\begin{array}{l}\text { Class teacher in the } \\
\text { classroom }\end{array}$ & Male \\
\hline 12. & Cassie & QLD & RA2 inner regional & Government & Kindergarten* & Injections & Mother in the classroom & Male \\
\hline 13. & Emma & SA & RA1 major city & Government & Reception* & Pump & $\begin{array}{l}\text { Student with class teacher } \\
\text { supervision in the classroom }\end{array}$ & Male \\
\hline \multicolumn{2}{|c|}{$\begin{array}{l}\text { Total } \\
n=14\end{array}$} & $\begin{array}{l}\text { NSW } 4 \\
\text { QLD } 5 \\
\text { SA } 1 \\
\text { VIC } 2 \\
\text { WA } 1 \\
\text { ACT } 1\end{array}$ & $\begin{array}{l}\text { RA1 } 9 \\
\text { RA2 } 4 \\
\text { RA3 } 1\end{array}$ & $\begin{array}{l}\text { Govt } 9 \\
\text { Catholic } 3 \\
\text { Ind. } 2\end{array}$ & $\begin{array}{ll}\text { Prep/Rec/K } 3 \\
\text { Grade } 1 & 7 \\
\text { Grade } 2 & 4\end{array}$ & $\begin{array}{l}\text { Pump } 10 \\
\text { Injections } 4\end{array}$ & & $\begin{array}{l}\text { M } 10 \\
\text { F } 4\end{array}$ \\
\hline
\end{tabular}

New South Wales (NSW) South Australia (SA) Western Australia (WA) Victoria (VIC) Queensland (QLD) Australian Capital Territory (ACT)

Major city (RA1) Inner regional (RA2) Outer regional (RA3)

${ }^{*}$ First year of compulsory school attendance aged 5 by April-June depending on Australian state/territory

\section{TABLE 5. RESULTS: NARRATIVE THREADS IN THE COMPOSITE NARRATIVE}

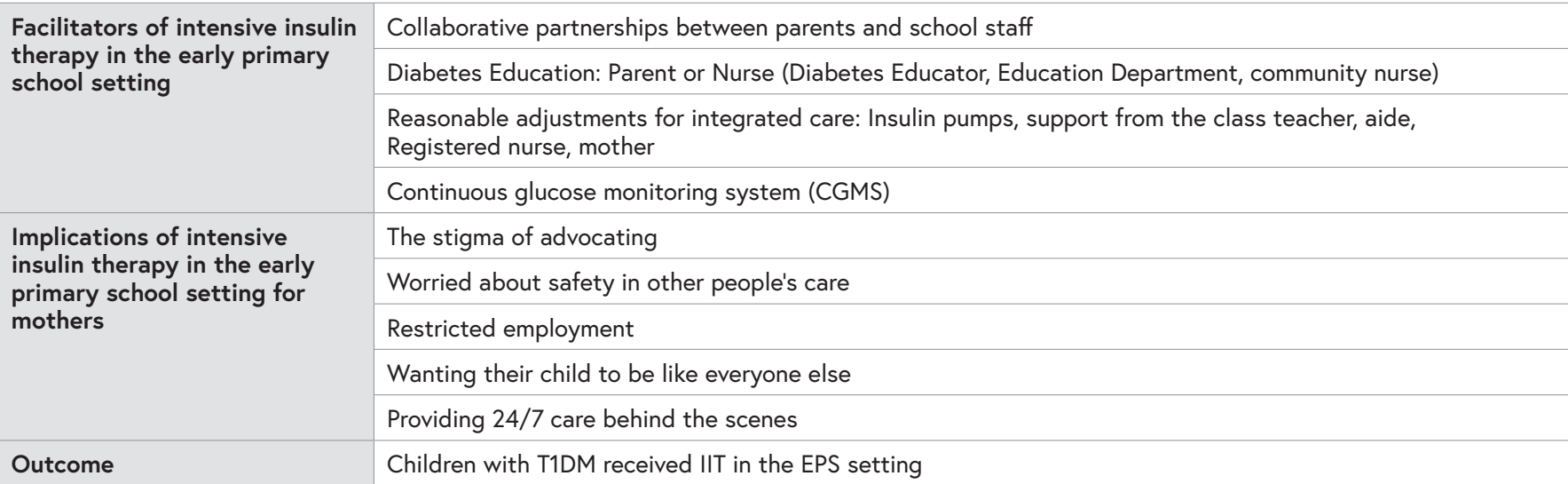




\section{FACILITATORS OF INTENSIVE INSULIN THERAPY SUPPORT}

\section{Collaborative partnerships between parents and school staff}

A collaborative relationship between parents and school staff enabled a smooth transition back to school after diabetes diagnosis or when starting school for the first time. Initial contact was usually with the school principal and a number of mothers spoke positively about these experiences. Principals were described as interested, supportive, accommodating and reassuring. These mothers felt the principal understood the seriousness of T1DM which facilitated the use of IIT for their child. Mothers worked in partnership with school staff and were readily available to provide ongoing support for their child. They made themselves available at the beginning of each school year to physically attend the school or take phone calls.

Most mothers had a non-demanding approach and did not 'expect too much' from the school. Four mothers were school teachers and understood 'the way schools work' and were mindful that 'a school is a school'. Mothers described their relationship with school staff as one of mutual respect and trust. They knew that staff were 'doing their best and sometimes mistakes happen'. They felt staff went 'above and beyond' for their child and mothers 'were eternally grateful'. Often these schools had a community feel where 'everyone knows everyone'.

In contrast, some mothers expressed their frustration when the principal put up 'road blocks' and 'didn't want to deal with diabetes at all.' These principals had a negative, nonaccommodating approach, without parental collaboration. This appeared to be driven by 'safety concerns' and potential legal issues related to the use of needles in the classroom for insulin injections and glucose testing.

Sadly, schools are constrained by too much red tape, a risk aware, health and safety workplace madness. Common sense just seems to go out the window. His blood glucose meter is lifesaving medical equipment. You wouldn't ask someone to leave a wheelchair at the main office to be brought down to class when they needed it. (Cassie)

Mothers who were previously known to the school experienced less problems than those who were new. Mothers described some teachers as fearful, panicked and worried about 'doing the wrong thing. Whilst others, were too blasé and 'didn't understand the seriousness of the condition'. The attitude of school staff was more positive once they gained experience and knew the student with diabetes was cooperative and pleasant.

\section{Diabetes Education}

Nurses external to the school system assisted both parents and school staff by providing diabetes education, support with care planning and promoting IIT. Support from nurses was particularly important when the student was newly diagnosed, and information was new to parents. Eight mothers reported that diabetes education and support was provided by either a diabetes educator from the hospital, a community/regional nurse, or a nurse from the Queensland Education Department. Nurses knew "what the school was capable of doing' and provided 'peace of mind' for mothers and school staff. Nurses, as qualified health professionals, provided credibility to requests for the accommodation of IIT rather than from 'just a panicked mother.' Six parents provided diabetes education to school staff mainly due to under resourced diabetes services or the impression that the parent was capable of providing their own education.

The diabetes educator at the hospital didn't want anything to do with the school as she was under resourced. It made it very difficult. I feel that if there had been the face of the nurse in front of the school then they would have been called to account and things would have been different. (Rhonda)

\section{Reasonable adjustments for integrated care}

All mothers expected reasonable adjustments to accommodate IIT at school. When there was not a supportive, collaborative relationship with the school principal and teaching staff, mothers had to advocate more extensively for their child.

\section{We were told that a child with diabetes is not entitled to the same care at school that they get at home. As a parent, I'm always going to advocate for my son. I know what he's entitled to and I'm willing to stand up and have those arguments. (Rachel)}

The spirit of the disability discrimination legislation is that the child must be able to access education on the same basis as others. Well, having to walk up to the administration office and miss out on part of your lunch or playtime is not on the same basis as others. (Cassie)

Thirteen mothers reported that their child was receiving IIT in the classroom and integrated into normal routines. Eight students (53\%) administered their own insulin with supervision. Insulin pumps were easier for young students and staff to manage. Pumps were perceived as less 'risky' than injections and provided more flexibility. For the majority of students (nine), classroom-based diabetes care required support from either the teacher (seven) and/or teacher's aide (six). Allocation of a teacher's aide provided 'an extra set of hands to take the pressure off class teachers.'

The teacher's aide went to every specialist class and was there at lunchtime to assist with diabetes care. Because the aide was assigned for him I could talk to her every day if I needed to. I didn't feel like I was hassling the classroom teacher all the time. (Maria)

The long-term allocation of a teacher's aide was not guaranteed, however, as funding for aide support was often 
not specifically for the student with diabetes. Rather, the aide was shared amongst a number of students with varied additional needs. When this support for diabetes care was not available, workload and stress levels increased for both the class teacher and mothers.

Initially, most mothers attended the school daily and administered or supervised insulin until their child, or a school staff member could take over care. Two mothers were attending the school on an ongoing basis to administer insulin via injection.

At the moment I wouldn't be willing to hand over the insulin injection to the school because I don't have that level of confidence in them and somebody has to be willing to volunteer. (Cassie)

Two students had assistance from a Registered nurse; a Year 1 student on insulin injections at an Independent school in NSW and a kindergarten student from a Government school in Victoria.

We didn't request that the teacher inject insulin. We enrolled her in a College that has two fulltime Registered nurses in a clinic. You don't get the gardener to come in and teach reading groups for Year 1. Let's give appropriate jobs to the appropriate staff. (Rhonda)

The school refuses to administer insulin, and I cannot blame them for that. I had to go to the Minister and threaten the Education Department with legal action to fund a Registered nurse to administer insulin via a pump at school. The good thing about having a nurse is that they're obligated to manage my child. You can completely and confidently handover to them. The Education Department said after six months they expect my son to give insulin himself. He can't do it; he can't read the numbers properly. (Rachel)

\section{Continuous glucose monitoring system}

Four students were using continuous glucose monitoring systems. This technology saved time, improved student safety and provided peace of mind to both teachers and parents who could access information 'at a glance' and remotely.

Having that alarm for the teachers took a lot of pressure off them. Instead of doing four or five glucose levels during the day when he kept saying he wasn't feeling well, they can look at the pump screen and say, oh look, you're about right. (Emma)

\section{IMPLICATIONS OF INTENSIVE INSULIN THERAPY SUPPORT}

\section{The stigma of advocating}

All mothers expressed concern about being labelled as the 'nutcase helicopter parent' when advocating for their child's needs.
You feel like you're treading that very fine line, especially when you've just started at a school, of becoming known as the parent who's the absolute pain and every teacher ducks their head when they see you coming to advocate for your child. (Cassie)

\section{Worried about safety in other people's care}

Mothers spent a significant amount of time planning for the transition to school or a new class teacher. This process created anxiety and uncertainty for mothers who were worried about safety and trusting school staff to assist with their child's diabetes care.

Her teacher this year has told the teacher for next year that Stephanie's quite capable of doing by herself. That actually scares me a bit. She was talking about it once and said mum, I put 81 into the pump instead of 18. (Amy)

Just because Steven's the first thing on my mind, doesn't mean that they're thinking about him 24/7 like I am. Which is a harsh reality when you've got this kid that needs constant monitoring. It's hard to come to terms with the fact that they're not anywhere near as in tune with him as you are, and they're not taking it as seriously. It's a tug of war on your heart and your brain, 24/7. (Maria)

\section{Restricted employment}

Mothers discussed the impact on their employment due to the need to be 'on call' to attend the school for emergencies and special events or to answer questions over the phone.

It's just what you do isn't it? I go to swimming or anything where there's sport or exercise. The teacher's eyes have to be everywhere, and my eyes are only on Sam and in that situation, I know the glucose level can drop really quickly. If I didn't have such a wonderful boss I would have had to quit. (Sharon)

There was one day where he cried to his aide and she rang me. She said Jacob doesn't want to go on his dance rehearsal tomorrow because he doesn't know who's going to look after him. I don't want him to miss out - so I took a day off work to take him. Sometimes I've had to make those sacrifices. I would do it in a heartbeat, but I just felt if I had more support, or if he felt confident with the people that were caring for him then he'd want to do more things. (Rebecca)

I don't work. I could go to work but I can guarantee at least two nights a week I'll be up until three o'clock in the morning. I would probably duck up to school three or four times a week. Some weeks I've been up there 10 times a week. Who wants to employ someone that has to leave for 20 minutes here or there? (Melissa)

\section{Wanting their child to be like everyone else}

Mother's expressed feelings of sorrow, they wanted their child to be 'normal' and participate in all school activities like children without diabetes. They were, however, mindful of the fact that having diabetes meant that their child was 
affected differently by activities that others could do without planning, testing blood glucose levels, adjusting insulin, or risking hypoglycaemia.

I feel really sad. I know it's a ridiculous word really to put to it. I don't care about doing the extra work. I care that it means that he is a little bit different. (Sharon)

I've been to the hospital to talk to a social worker, I get myself all frustrated because I sometimes think I'm doing all I can do, but maybe that's not enough because the teacher isn't coping. I really think the teacher is scared. I understand that totally. But he deserves a good life too, and not to be different. So, I just have to fight for him because no-one else will. (Rebecca)

You want him to be completely normal, but you know all those things that the other kids are doing, are going to affect his sugar level. (Maria)

\section{Providing 24/7 care behind the scenes}

In addition to providing direct school support, the planning required 'behind the scenes' to manage diabetes took a significant toll on mothers, physically and mentally.

It does end up taking over your day. Yesterday the school rang me because his glucose was high. I spoke to the school nurse, the diabetes educator and then I look at the clock and say to my daughter, it's time for your sleep, little one. I haven't spent any time with you this morning. You're trying not to make it all about diabetes but in reality, it's always there because you have to be aware of what they're eating, what activity they're doing, have they had insulin. My analogy is - it's like the duck, it looks absolutely beautiful, peaceful and graceful on top of the water, but under the water those legs are going 19 to the dozen, that's what it's like managing a child with diabetes. It is life and death.(Cassie)

Behind the scenes is 99\% of it. What people see - him finger prick and the injection; they'd be like 'oh gee he has to have an injection'. I'm like, that takes three seconds. The 23 and a half hours of the rest of the day, is thinking about what he's going to eat, when he's going to eat it, how it's going to affect his sugar level. Is it going to be hot, are we going for a swim today, what time's snack going to be? Oh my god these are the things that send you nuts. (Maria)

Mothers spoke about hiding their feelings of stress related to planning and managing diabetes care at school from their child. They felt that having diabetes was enough to deal with already and they didn't want their child to see them upset.

I do a lot of the worrying out of sight, I don't worry about it in front of him. I don't let him see me thinking how many grams of carbohydrates is that sausage roll, how am I going to add this up. I don't want him to think that his condition is a burden on me. (Maria)

\section{DISCUSSION}

\section{FACILITATORS OF INTENSIVE INSULIN THERAPY SUPPORT}

\section{Diabetes Education}

Mothers in this study identified diabetes education as a facilitator of IIT support. Historically, diabetes education in Australia was provided by nurses from hospital based diabetes services on school grounds. ${ }^{39}$ However, withdrawal of this support has recently occurred due to the increased number of children with T1DM and the lack of additional staffing. ${ }^{39}$ Alternative options evolved, including Diabetes Australia education seminars, ${ }^{39}$ Education Queensland nurses, ${ }^{39}$ private diabetes educators, ${ }^{39,40}$ and parents. ${ }^{39,40}$ Some school teachers used internet sources when they were unable to gain support from a diabetes educator..$^{\circ}$ This is concerning considering reports about teacher's limited diabetes knowledge affecting their confidence in supporting students with diabetes. ${ }^{5}$ These varied options highlight an adhoc and inconsistent approach to diabetes education in Australia with impacts for the overall schooling experience for children with diabetes.

Diabetes education is the foundation for IIT support, providing knowledge and skills to enable understanding and increased confidence. ${ }^{40}$ It provides theoretical knowledge and an understanding of concepts for problem solving. However, skill development for IIT support requires training and real-life practice to develop and maintain competence..$^{40}$ The benefit of formal diabetes training has been highlighted in the literature. 57 Skills training and ongoing assistance from diabetes educators could potentially reduce feelings of stress, anxiety and burden of responsibility for teachers who volunteer to assist with IIT. ${ }^{\circ}$

The Australian Paediatric Society recommend three levels of diabetes education and training: (1) Introductory education for all school staff, (2) Intermediate education for school staff responsible for the child with T1DM and (3) Individualised skills training for staff supervising or administering insulin..$^{8}$ Standardised diabetes training should be provided before the child commences school, with follow-up training if required. ${ }^{6}$ This is essential to ensure teachers feel adequately prepared, children are safe, and parents have confidence in the school. Yet, diabetes educators are unable to provide this level of school support in all areas. ${ }^{28,59}$

The Australian Government has recently funded the T1D Management in Schools Program. ${ }^{60}$ This national program includes online training and education available to all school staff (Levels 1 and 2) and individualised face-to-face skills training (Level 3) for selected schools where students have high needs. This program provides a nationally consistent approach for three levels of training. ${ }^{61}$ Level 3 training on school grounds is individualised for a particular student and provided by a health professional from their usual diabetes team where possible. 
This program aligns with the Australian National Diabetes Strategy Implementation Plan; to promote awareness of T1DM symptoms and management in schools. ${ }^{62}$ However, the government is yet to fully address strategies for improving workforce capacity to make schools diabetes safe environments. ${ }^{63}$ Rather than only allocating level 3 diabetes training for selected schools, additional funding is required to increase the number of diabetes educators so that all school staff, parents and students can receive the necessary level of specialised support for IIT.

\section{Reasonable adjustments for integrated care}

The majority of mothers reported that schools made reasonable adjustments to facilitate integrated diabetes care. Class teachers, aides and nurses supported IIT, but there was no guarantee of ongoing support. This lack of consistency is comparable to other research and created uncertainty for mothers. 39,40

The medical aspects of diabetes care have been reported by teachers as overwhelming and associated with increased burden of responsibility when working outside their usual scope of practice. ${ }^{39}$ Their attention was diverted away from core teaching responsibilities when assisting students with diabetes care. ${ }^{64,65}$ It is unreasonable to expect class teachers to be responsible for IIT in addition to providing a duty of care for the remaining students in the classroom without additional staff assistance.

Mothers in this study spoke about the benefit of a teachers' aide to provide consistency for diabetes care and relieve the pressure off class teachers. School teachers also reported reduced burden when diabetes care was shared with a teacher's aide. $4^{\circ}$ Unfortunately, the long-term funding and allocation of a teacher's aide was not guaranteed for children in this study, and the aide was often shared amongst a number of students. When aide support was not available, workload and stress levels increased for both the class teacher and mothers. Furthermore, the availability of teacher's aide support for students with T1DM varies across Australia. ${ }^{31}$ The lack of a consistent approach creates inequality and has the potential for negative health and educational outcomes for students.

\section{IMPLICATIONS FOR MOTHERS}

This study highlights that when a child with T1DM enters the Australian school system, a consistent, formal support structure is lacking. Care is negotiated on a case-by-case basis and is dependent on the availability of a staff member to volunteer to administer or supervise insulin therapy. Parents were expected to provide consent for non-health professionals to administer or supervise insulin for their child at school. The lack of qualified registered nurses places undue pressure on mothers to constantly be on call to make clinical decisions, with implications for emotional and physical wellbeing as well as potential social and economic disadvantage. The uncertainty of ongoing volunteer support from non-nursing school staff also creates distress for mothers and potentially their children.

There is an obvious disconnect between mandatory school attendance, accessing education on the same basis as others according to the Disability Standards for Education, and the availability of school nurses to legally administer insulin.

Schools are mandated to make reasonable adjustments for students with T1DM. However, many schools lack adequate resources to provide this individualised support and the burden falls on to mothers. Other studies found that parents were always on alert, in a chronic vigilant state, which caused feelings of panic, worry, fear and anxiety. ${ }^{30,66}$ The inability to confidently hand over care during the school day and the requirement to always be on call has significant emotional and physical impacts for mothers.

The added burden of diabetes care on mothers during the EPS years when children require the most support results in social and economic disadvantage as they put their lives on hold until their child is more independent. Lower levels of life satisfaction, socioeconomic status and labour force participation have been reported in parents caring for children with disabilities. ${ }^{67,68}$ Carer responsibilities were associated with fatigue and stress with significant impacts on parental mental health.

Some mothers in this study were required to administer insulin at school each day. They sacrificed employment or family commitments to attend special school events due to concerns about hypoglycaemia and the lack of available school staff supervision. Likewise, parents in other studies experienced disruptions to their employment due to the inadequacy of school support. ${ }^{34,35,37,70}$ Parents should not be expected to fill the gap in appropriate health support when resources are inadequate. ${ }^{69}$

\section{SCHOOL NURSES}

Although support from a class teacher or aide was available for many students in this study, it was on a voluntary basis. The benefit of a school nurse is that they are employed specifically for the purpose of healthcare, they have appropriate qualifications and legal coverage for insulin administration. A registered nurse would enhance safety for the student with diabetes and reduce the burden on parents. ${ }^{30,71}$ In addition, improvements for children in quality of life, classroom participation and diabetes control, ${ }^{72}$ increased productivity of class teachers and parents, and reduced healthcare costs have been reported. ${ }^{73}$

There are 9,769 schools in Australia 74 and approximately 1,500 school nurses, ${ }^{75}$ clearly highlighting a shortage in services. According to the Australian National School Nursing Professional Practice Standards, the role of school nurses includes formulating care plans and providing healthcare. ${ }^{76}$ However, the majority of schools nurses are not 
available to assist with the direct management of chronic health conditions. It is unclear why all Australian schools do not have full time nurses on site, but it is most likely due to limited budgets and the lack of awareness about the importance of the role. For example, school nurses were removed from Queensland due to health service budget constraints. ${ }^{77}$ As an alternative, the State Schools Nursing Service was funded by the Education Department. ${ }^{8}$ However, these nurses do not provide direct care or health screening, rather, they assess health conditions, develop care plans and train non-nursing school staff to directly support students.

In contrast, the Tasmanian Government have committed to fund school nurses across all government schools. ${ }^{79}$ However, these full-time school nurses are responsible for a number of schools which limits their ability to physically assist with the individual management of chronic health conditions. NSW have funded a school-based nursing program focused on mental health for selected schools deemed most in need. ${ }^{80}$ These recent budget commitments from individual Australian State Governments demonstrate an appreciation of the important role of school nurses. Yet, additional funding is required so that every school has the appropriate number of full-time registered nurses to provide the necessary level of specialised support for all students, including children with T1DM.

\section{STRENGTHS AND LIMITATIONS}

This study is the first to provide qualitative insight into the experience of Australian mothers supporting their child with T1DM using IIT in the EPS setting. Data were collected from a small group of participants from six out of eight Australian states/territories, regional and city geographical areas, Government and non-Government schools, and students from kindergarten/reception/preparatory, Grade 1 and 2, with both insulin injections and pump therapy.

Limitations of the study include lack of input from the remaining two Australian states/territories and fathers. Recruitment via Facebook may not have been the appropriate method to target fathers. With the sample size and methods used, the findings may not capture all mothers' narratives related to IIT support in EPS. For example, mothers who are not well educated or unable to speak English.

\section{CONCLUSION AND IMPLICATIONS FOR NURSING AND HEALTH POLICY}

The findings of this study indicate that the Australian education system lacks appropriate health support structures for children with T1DM. It is beyond the school workforce's scope of practice to provide specialised healthcare that is required to participate fully and safely in the school experience. In order to facilitate IIT at school non-nursing staff are trained to administer or supervise insulin and the overall responsibility is transferred onto parents. Parents are expected to provide consent for non-nursing staff to support diabetes care and ultimately, accept substandard diabetes care contradictory to what is expected in the home environment.

Nurses working as diabetes educators need to be aware of the burden on mothers and advocate for more supportive practices to facilitative IIT in the EPS setting. Parents, in collaboration with health and education departments, should demand the allocation of appropriately qualified school nurses to legally provide high quality diabetes care to which the children are entitled to. If current practices, dictated by insufficient resources continue, the Australian Government will make the assumption that existing systems are adequately meeting the needs of students with T1DM.

Acknowledgements: The authors would like to thank the mothers who participated in the study.

Human Ethics Approval Statement: The ethics committees from Western Sydney University granted ethical approval for this study.

Funding support: There was no funding support for this research.

Conflict of interests: The authors declare that there are no conflicts of interest in connection with this article.

\section{REFERENCES}

1. Mayer-Davis EJ, Kahkoska AR, Jefferies C, Dabelea D, Balde N, Gong CX, et al. ISPAD Clinical Practice Consensus Guidelines 2018: Definition, epidemiology, and classification of diabetes in children and adolescents. Pediatr Diabetes. 2018; 19(S27): 7-19. Available from: https://doi.org/10.1111/pedi.12773

2. Haynes A, Bulsara MK, Bergman P, Cameron F, Couper J, Craig $M E$, et al. Incidence of type 1 diabetes in 0 to 14 year olds in Australia from 2002 to 2017. Pediatr Diabetes. 2020; 21(5): 707-12. Available from: https://doi.org/10.1111/pedi.13025

3. International Diabetes Federation. Type 1 diabetes estimates in children and adolescents. International Diabetes Federation. 2019. [cited 2020 Jan 30] Available from: https://www. diabetesatlas.org/data/en/indicators/11/

4. Australian Institute of Health and Welfare. Australia's children. Australian Institute of Health and Welfare. 2020. [cited 2020 Jan 30] Available from: https://www.aihw.gov.au/reports/ children-youth/australias-children/contents/executivesummary

5. Bell MF, Bayliss DM, Glauert R, Harrison A, Ohan JL. Chronic illness and developmental vulnerability at school entry. Pediatrics. 2016; 137(5), e20152475. Available from: https://doi.org/10.1542/peds.2015-2475

6. Marks A, Wilson V, Crisp J. The management of type 1 diabetes in primary school: review of the literature. Issues Compr Pediatr Nurs. 2013; 36(1-2): 98-119. Available from: https://doi.org/10.31 09/01460862.2013.782079

7. Danne T, Bangstad HJ, Deeb L, Jarosz-Chobot P, Mungaie L, Saboo $B$, et al. Insulin treatment in children and adolescents with diabetes. Pediatr Diabetes. 2014; 15(S20): 115-34. Available from: https://doi.org/10.1111/pedi.12184 
8. Diabetes Control and Complications Trial Research Group. The effect of intensive treatment of diabetes on the development and progression of long-term complications in insulin-dependent diabetes mellitus. N Engl J Med. 1993 329(14), 977-86. Available from: https://doi.org/10.1056/ nejm199309303291401

9. Craig M, Twigg S, Donaghue K, Cheung N, Cameron F, Conn $J$, et al. National evidence-based clinical care guidelines for type 1 diabetes in children, adolescents and adults. Australian Government Department of Health and Ageing. Canberra. 2011. [cited 2020 Jan 30] Available from: https://diabetessociety. com.au/documents/Type1guidelines14Nov2011.pdf

10. Donaghue KC, Marcovecchio ML, Wadwa RP, Chew EY, Wong TY, Calliari LE, et al. ISPAD Clinical Practice Consensus Guidelines 2018: Microvascular and macrovascular complications in children and adolescents. Pediatr Diabetes. 2018; 19(S27): 262-74. Available from: https://doi.org/10.1111/ pedi.12742

11. International Diabetes Federation. Global IDF/ISPAD guideline for diabetes in childhood and adolescence. International Diabetes Federation. 2011. [cited 2020 Jan 30] Available from: https://www.idf.org/e-library/guidelines/80-the-global-idfispad-guidelines-for-diabetes-in-childhood-and-adolescence. $\underline{\text { html }}$

12. Education Act 1990 No 8 (NSW). Available from: https://www.legislation.nsw.gov.au/view/whole/html/inforce/ current/act-1990-008\#sec.21B

13. Lin HP, Mu PF, Lee YJ. Mothers' experience supporting life adjustment in children with T1DM. West $J$ Nurs Res. 2008; 30(1): 96-110. Available from: https://doi. org/10.1177\%2F0193945907302456

14. Commonwealth of Australia. Disability standards for education. Commonwealth of Australia. 2005. [cited 2020 Jan 30] Available from: https://www.education.gov.au/disabilitystandards-education-2005

15. Disability Discrimination Act 1992 (Cth). [cited 2020 Feb 6] Available from: https://www.legislation.gov.au/Details/ C2018C00125

16. United Nations. Convention on the rights of persons with disabilities. United Nations. 2008. [cited 2020 Feb 6] Available from: http://www.un.org/disabilities/documents/convention/ convoptprot-e.pdf

17. Equal Opportunity Employment Commission. Disability defined and rules of construction. Equal Opportunity Employment Commission. 2008. [cited 2020 Feb 6] Available from: https://www.eeoc.gov/laws/statutes/adaaa.cfm

18. Equality Act 2010. Available from: https://www.legislation.gov. uk/ukpga/2010/15/contents

19. European Equality Law Network. 2017. European Equality Law Network. [cited 2020 Feb 6] Available from: http://www. equalitylaw.eu

20. Health (Drugs and Poisons) Regulation (Q/d) 1996. [cited 2020 Feb 6] Available from: https://www.legislation.qld.gov.au/view/ html/inforce/current/sl-1996-0414

21. Victoria Government. Drugs, poisons and controlled substances regulations. Victoria Government. 2017. [cited 2020 Feb 6] Available from: https://www.vic.gov.au/sites/default/ files/2019-11/Drugs-Poisons-and-Controlled-SubstancesRegulations-2017-Draft-Regulation.pdf

22. Poisons and Therapeutic Goods Regulation (NSW) 2002. [cited 2020 Feb 6] Available from: https://www.legislation.nsw. gov.au/view/html/inforce/current/sl-2008-0392
23. Controlled Substances (Poisons) Regulations (SA) 2011. [cited 2020 Feb 6] Available from: https://www.legislation.sa.gov.au/ LZ/C/R/CONTROLLED\%2OSUBSTANCES\%2O(POISONS)\%20 REGULATIONS\%202011/CURRENT/2011.140.AUTH.PDF

24. Australian Paediatric Society. Type 1 diabetes at school. Australian Paediatric Society. 2019. [cited 2020 Jan 30] Available from: https://learning.t1d.org.au/

25. Goss PW, Middlehurst A, Acerini CL, Anderson BJ, Bratina N, Brink $S$, et al. ISPAD position statement on type 1 diabetes in schools. Pediatr Diabetes. 2018; 19(7): 1338-41. Available from: https://doi.org/10.1111/pedi.12781

26. Pal R, Edge J. Oxfordshire childrens diabetes -the primary schools intervention programme. BMJ Open Qual. 2013; 2(1): u201068-w692. Available from: https://doi.org/10.1136/ bmjquality.u201068.w692

27. Jackson CC, Albanese-O'Neill A, Butler KL, Chiang JL, Deeb LC, Hathaway K, et al. Diabetes care in the school setting: a position statement of the American Diabetes Association. Diabetes Care. 2015; 38(10): 1958-63. Available from: https://doi.org/10.2337/dc15-1418

28. Marks A, Wilkes L, Blythe S, Griffiths R. Intensive insulin therapy in the primary school setting: A meta-ethnographic synthesis. Int Diabetes Nurs. 2016; 13(1-3): 2-13. Available from: https://doi.org/10.1080/20573316.2015.1126938

29. Freeborn D, Loucks CA, Dyches T, Roper SO, Mandleco B. Addressing school challenges for children and adolescents with type 1 diabetes: the nurse practitioner's role. J Nurse Pract. 2013; 9(1): 11-6. Available from: https://doi.org/10.1016/j. nurpra.2012.11.005

30. Nieto-Eugenio I, Ventura-Puertos PE, Rich-Ruiz M. SOS! My child is at school: a hermeneutic of the experience of living a chronic disease in the school environment. J Pediatr Nurs. 2020; 53: E171-178. Available from: https://doi.org/10.1016/j. pedn.2020.03.016

31. Marks A, Wilson V, Crisp J. Type 1 diabetes in Australian primary schools: parental concerns and strategies for improvement. Aust Diabetes Educ. 2014; 17(4): 12-8. Available from: https://www.researchgate.net/publication/268390917 Type 1 diabetes in Australian_primary schools Parental concerns and strategies for improvement

32. Nurmi MA, Stieber-Roger K. Parenting children living with type 1 diabetes: a qualitative study. Diabetes Educ. 2012; 38(4): 530-6. Available from: https://doi.org/10.1177\%2F0145721712446636

33. Smaldone A, Ritholz MD. Perceptions of parenting children with type 1 diabetes diagnosed in early childhood. J Pediatr Health Care. 2011; 25(2): 87-95. Available from: https://doi.org/10.1016/j.pedhc.2009.09.003

34. Amillategui B, Mora E, Calle JR, Giralt P. Special needs of children with type 1 diabetes at primary school: perceptions from parents, children, and teachers. Pediatr Diabetes. 2009; 10(1): 67-73. Available from: https://doi.org/10.1080/20573316. 2015.1126938

35. Lange K, Jackson C, Deeb L. Diabetes care in schoolsthe disturbing facts. Pediatr Diabetes. 2009; 10(S13): 28-36. Available from: https://doi.org/10.1111/j.13995448.2009.00613.x

36. Pinelli L, Zaffani S, Cappa M, Carboniero V, Cerutti F, Cherubini $V$, et al. The ALBA project: an evaluation of needs, management, fears of Italian young patients with type 1 diabetes in a school setting and an evaluation of parents' and teachers' perceptions. Pediatr Diabetes. 2011; 12(5): 485-93. Available from: https:// doi.org/10.1111/i.1399-5448.2010.00722.x 
37. Schwartz FL, Denham S, Heh V, Wapner A, Shubrook J. Experiences of children and adolescents with type 1 diabetes in school: survey of children, parents, and schools. Diabetes Spectr. 2010; 23(1): 47-55. Available from: https://doi.org/10.2337/diaspect.23.1.47

38. Whittemore R, Urban AD, Tamboriane WV, Grey M. Quality of life in school-aged children with type 1 diabetes on intensive treatment and their parents. Diabetes Educ. 2003; 29(5): 847-54. Available from: https://doi.org/10.1177\% 2F014572170302900514

39. Marks A, Wilson NJ, Blythe S, Johnston C. Facilitation of intensive insulin therapy in the early primary school setting: narratives of Australian diabetes educators. Compr Child and Adolesc Nurs. 2018; 41(3), 213-27. Available from: https://doi.org/10.1080/24694193.2018.1470703

40. Marks AL, Wilson NJ, Blythe S, Johnston C. The health promotion role of Australian early primary school teachers supporting students with type 1 diabetes. Health Promot $J$ Austr. 2020; 31(2): 240-50. Available from: https://doi.org/10.1002/hpja.274

41. Australian Diabetes Educators Association. Credentialling and education. Who is a Credentialled Diabetes Educator (CDE)? Australian Diabetes Educators Association. 2020. [cited 2020 Jan 30]. Available from: https://www.adea.com.au/ credentialling/

42. Polkinghorne DE. Narrative configuration in qualitative analysis Int J Qual Stud Educ. 1995; 8(1): 5-23. Available from: https://doi.org/10.1080/0951839950080103

43. Polkinghorne DE. Narrative knowing and the human sciences Albany: State University of New York Press; 1998.

44. Brown J, Addington-Hall J. How people with motor neurone disease talk about living with their illness: a narrative study. J Adv Nurs. 2008; 62(2): 200-8. Available from: https://doi.org/10.1111/j.1365-2648.2007.04588.x

45. Edwards SL. Narrative analysis: how students learn from stories of practice. Nurse Res. 2016; 23(3): 18-25. Available from: https://doi.org/10.7748/nr.23.3.18.s5

46. King J, Overland J, Fisher M, White K. Severe hypoglycemia and the role of the significant other: expert, sentry, and protector. Diabetes Educ 2015; 41(6): 698-705. Available from: https://doi.org/10.1177\%2F0145721715606223

47. Law BY, Chan EA. The experience of learning to speak up: a narrative inquiry on newly graduated registered nurses. J Clin Nurs. 2015; 24(13-14): 1837-48. Available from: https://doi.org/10.1111/jocn.12805

48. Martinie SL, Kim JH, Abernathy D. "Better to be a pessimist": a narrative inquiry into mathematics teachers' experience of the transition to the Common Core. J Educ Res. 2016; 109(6): 658-65. Available from: https://doi.org/10.1080/00220671.201 $\underline{5.1020913}$

49. Bruner JS. Actual minds, possible worlds. Massachusetts: Harvard University press; 1985.

50. Kearney MP. Reconfiguring the future: stories of post-stroke transition [dissertation]. Adelaide: University of South Australia; 2009. Available from: https://find.library.unisa.edu.au/primoexplore/fulldisplay?id=9915960273801831\&vid=ROR\&sortby =rank\&lang=en US

51. Lincoln YS. Naturalistic inquiry. The Blackwell encyclopedia of sociology; 2007. Available from: https://doi. org/10.1002/9781405165518.wbeosn006

52. Riessman CK. Narrative methods for the human sciences. California: Sage; 2008
53. Ollerenshaw JA, Creswell JW. 'Narrative research: a comparison of two restorying data analysis approaches'. Qual Inq. 2002; 8(3): 329-47. Available from: https://doi.org/10.1177\%2F10778004008003008

54. Bruner JS. Acts of meaning. Massachusetts: Harvard University Press; 1990.

55. Stroobants V. Stories about learning in narrative biographical research. Int J Qual Stud Educ. 2005; 18(1): 47-61. Available from: https://doi.org/10.1080/09518390412331318441

56. Diabetes Australia. Diabetes in schools. a report on the issues related to a safe and supported environment for children and young people in schools and preschools in Australia; 2017. Diabetes Australia. 2017. [cited 2020 April 22]. Available from: https://www.diabetesaustralia.com.au/wp-content/uploads/ Diabetes-in-schools-report-2017.pdf

57. Boden S, Lloyd CE, Gosden C, Macdougall C, Brown N, Matyka K. The concerns of school staff in caring for children with diabetes in primary school. Pediatr Diabetes. 2012; 13(6), e6-e13. Available from: https://doi.org/10.1111/j.1399$\underline{5448.2011 .00780 . x}$

58. Australian Paediatric Society. Type 1 diabetes. Australian Paediatric Society. 2021. [cited 2021 April 2] Available from: https://www.t1d.org.au

59. Marshall M, Gidman W, Callery P. Supporting the care of children with diabetes in school: a qualitative study of nurses in the UK. Diabet Med. 2013; 30(7), 871-877. Available from: https://doi.org/10.1111/dme.12154

60. Hunt G. Press release, World Diabetes Day - $\$ 6$ million Initiative to be ready for new school year. 2019. [cited 2021 April 2] Available from: https://www.greghunt.com.au/world-diabetesday-6-million-initiative-to-be-ready-for-new-school-year/

61. Diabetes Australia. New diabetes in schools program will help reduce the impact of type 1 diabetes for students, parents and schools. Diabetes Australia. 2020. [cited 2021 April 2] Available from: https://www.diabetesaustralia.com.au/mediarelease/ new-diabetes-in-schools-program-will-help-reduce-the-impactof-type-1-diabetes-for-students-parents-and-schools/

62. Australian Health Ministers' Advisory Council. Diabetes in Australia: focus on the future. The Australian National Diabetes Strategy 2016-2020 Implementation Plan. Australian Health Ministers' Advisory Council. 2017. Available from: https:// www.health.gov.au/sites/default/files/documents/2019/09/ implementation-plan-for-the-australian-national-diabetesstrategy-2016-2020.pdf

63. Australian Government Department of Health. Australian National Diabetes Strategy 2016-2020. Australian Government Department of Health. 2015. Available from: https://www. health.gov.au/resources/publications/australian-nationaldiabetes-strategy-2016-2020

64. Hill NJ, Hollis M. Teacher time spent on student health issues and school nurse presence. J Sch Nurs. 2011; 28(3), pp. 181-86. Available from: https://doi.org/10.1177\%2F1059840511429684

65. Olson AL, Seidler AB, Goodman D, Gaelic S, Nordgren R. School professionals' perceptions about the impact of chronic illness in the classroom. Arch Pediatr Adolesc Med. 2004; 158(1), pp. 53-8. Available from: https://doi.org/10.1001/archpedi.158.1.53

66. Kingod N, Grabowski D. In a vigilant state of chronic disruption: how parents with a young child with type 1 diabetes negotiate events and moments of uncertainty. Sociol Health IIIn. 2020; 42(6): 1473-87. Available from: https://doi.org/10.1111/14679566.13123 
67. Cummins RA, Hughes J, Tomyn A, Gibson A, Woerner J, Lai L. The Wellbeing of Australians-Carer Health and Wellbeing (Australian Unity Wellbeing Index Survey 17.1). Deakin University. 2007. Available from: http://hdl.handle. net/10536/DRO/DU:30010534

68. Raina P, O'Donnell M, Rosenbaum P, Brehaut J, Walter SD, Russell $D$, et al. The health and well-being of caregivers of children with cerebral palsy. Pediatrics. 2005; 115(6): e626-36. Available from: https://doi.org/10.1542/PEDS.2004-1689

69. Bratina N, Forsander G, Annan F, Wysocki T, Pierce J, Calliari $\mathrm{LE}$, et al. Management and support of children and adolescents with type 1 diabetes in school. Pediatr Diabetes. 2018; 19(27): 287-301. Available from: https://doi.org/10.1111/pedi.12743

70. Heilporn G, Laberge M, Côté A, Rekik M. From diagnosis to routine care in type 1 diabetes in children: parents' experiences. Patient Exp J. 2019; 6(3): 42-9. Available from: https://doi.org/10.35680/2372-0247.1372

71. Stefanowicz A, Stefanowicz J. The role of a school nurse in the care of a child with diabetes mellitus type 1-the perspectives of patients and their parents: Literature review. Zdr Varst. 2018; 57(3): 166-74. Available from: https://doi.org/10.2478/sjph2018-0021

72. Best NC, Oppewal S, Travers D. Exploring school nurse interventions and health and education outcomes: an integrative review. J Sch Nur. 2018; 34(1), 14-27. Available from: https://doi.org/10.1177\%2F1059840517745359

73. Wang LY, Vernon-Smiley M, Gapinski MA, Desisto M, Maughan $\mathrm{E}$, Sheetz A. Cost-benefit study of school nursing services. JAMA Pediatr. 2014; 168(7), 642-8. Available from: https://doi. org/10.1001/jamapediatrics.2013.5441

74. Australian Schools Directory. 2021. [cited 2021 April 2] Available from: https://www.australianschoolsdirectory.com.au/ search-schools

75. Fedele R. New national practice standards for school nurses released. Australian Nursing and Midwifery Federation. 2019 [cited 2021 April 2] Available from: https://anmj.org.au/newnational-practice-standards-for-school-nurses-released/

76. Ward M. National school nursing professional practice standards - 2nd edition. Australian Nursing and Midwifery Federation. 2012. Available from: https://www.anmf.org.au/ pages/school-nursing-standards

77. Jabour B. School nurses axed. Brisbane Times. 2013. [cited 2021 April 2] Available from: https://www.brisbanetimes.com.au/ national/queensland/school-nurses-axed-20130123-2d7rb.html

78. Queensland Government Department of Education. State schools nursing service practice guide. Queensland Government Department of Education. 2020. [cited 2021 April 2] Available from: https://education.qld.gov.au/student/Documents/stateschools-nursing-service-practice-guideline.pdf

79. Rockliff J. Media release: supporting mental health and wellbeing in our schools. 2020. [cited 2021 April 2] Available from: http://www.premier.tas.gov.au/site resources 2015/ additional releases/supporting mental health and wellbeing in our schools

80. New South Wales Government. \$46.8 million to expand wellbeing nurses in schools program. New South Wales Government. 2020. [cited 2021 April 2] Available from: https://education.nsw.gov.au/news/latest-news/-46-8-millionto-expand-wellbeing-nurses-in-schools-program 